\title{
Realize Village Government Governance Through Social Capital Potential
}

\author{
Bambang Martin Baru* Sripeni Rusbiyanti Harianto \\ Faculty of Social and Political Sciences, Universitas Merdeka Madiun
}

\begin{abstract}
Social capital is a potential social resource if there is a synergy between the government's program objectives and the interests of the villagers. However, in practice, the attention of the village government to the potential of social capital is relatively limited, and even tends to ignore the meaning of the potential of social capital. In terms of social capital as a potential it can be utilized to support government functions. Through the development of potential social capital will result in synergic cooperation in dealing with various social challenges currently faced. Therefore, to realize good village governance, the support of villagers is needed, while globalization has eroded and eroded the potential of the villagers' social capital. For this reason, the commitment of the village government is needed to always care through the orientation of the policies produced and actions that are concerned with the interests of the villagers, so as to foster public trust in the village administration. With the growth of public trust in village government can increase the role of the community in order to realize good village governance
\end{abstract}

Keywords: Village Government, Good Governance, Social Capital.

DOI: $10.7176 / \mathrm{RHSS} / 9-12-16$

Publication date:June $30^{\text {th }} 2019$

\section{INTRUDUCTION.}

Globalization and democracy have swept in various parts of the life of society, including rural areas, including the rapid changes in community life. These social changes, encourage the increasing demands of the community for changes in the system of governance. Community demands for transparency and accountability in the performance of village governance increasingly indicate a crisis of trust in government administrators. Many of the village development policies produced are not representative of the interests of the villagers, but rather the interests of a small proportion of village elites. As a result the village development program is not able to be the right solution in overcoming the social problems that are being faced by the villagers. While the involvement of villagers in the process of formulating village policies is only limited to fulfilling the provisions of formalities, so that they appear to be reflected as if the village policy-making process took place democratically.

The preparation of the village policy became one of the obstacles to bring the village development goals closer to the interests of the villagers, as a result of the village community being apathetic, the ignorance of what was carried out by the village government. If this condition continues and continues, the equitable development of equitable development is still very far from the expectations of the wider community. For this reason, the involvement of villagers is needed in every stage of village development policy formulation, starting from problem identification activities and work program preparation, to the implementation and utilization of village development results. The involvement of the villagers in the process of identifying and developing development policies is expected to be able to bring closer between the wishes, willingness and expectations of the villagers, which can later be taken into consideration in the formulation and formulation of village development policies. The involvement of the villagers has a strategic function because the villagers will give full support for the success in implementing development and at the same time will maintain the utilization of the results of village development. Meanwhile, village government organizers still doubt the potential of the villagers in supporting the success of village development, in the case of various studies concluding that the villagers have the potential for social capital that has developed since hereditary and has become a binding tradition for all members of the village can be utilized to support various community activities. The results of the study by Martin Baru, et al. (2018), show that: villagers have the potential for potential social capital to support governance and village development. It's just that the potential for social capital has not received serious attention from the government, especially the village government, to be able to be maximally utilized in supporting the functions of the village government. Furthermore, from the findings of Martin Baru's research, et al. (2018), it was shown that: the social capital of villagers is still potential, the element of trust among fellow villagers is still highly upheld in community life, and even the value of trust becomes a basic value and dignity for villagers. Likewise the value of togetherness is reflected in the involvement of villagers in various social activities quite well, especially activities involving public interests play an active role in it. Social norms and values are still very strong in guiding their social life, such as the value of mutual cooperation, togetherness, mutual help, help, and so forth. It's just the problem, there is no synergy between the potential of social capital and the potential of village apparatus resources, as a result there has not yet been the realization of the trust of the villagers towards the village administration.

Trusts can be built through actions and policies that are produced must really reflect the needs of the village 
community. Actions are intended as attitudes and behavior of village officials who are able to show the community as servants of the community. The village apparatus must have an attitude to always pay attention when the villagers have difficulties in managing public services, and even have to guide, directing them to resolve the difficulties they face. Likewise, with policies specifically concerning village development there must be alignments with the interests of the villagers. The involvement of the village community in the development process is not only measured by its involvement in the village discussion forum, but the results of the village meeting can be actualized into the village development program. If the community believes that the village development program produced will actually be the result of village meetings, the community will provide positive support for the implementation of village development. It is this trust that is able to grow the potential of the villagers' social capital, which is realized through mutual cooperation activities, self-reliance and participation in the administration of village governance. Mutual cooperation, according to Kusnaedi (2006), is a positive attitude that supports village development and also needs to be maintained as a manifestation of the habit of doing joint work. Mutual cooperation as a form of cooperation carried out by villagers, such as working to clean the social environment, roads, waste. mutual cooperation is a positive attitude that supports village development and also needs to be maintained as a manifestation of the habit of doing joint work. Mutual cooperation as a form of cooperation carried out by villagers, such as working to clean up the social environment, roads, waste (Martin Baru, et al, 2017). In Widjaja (2004), mutual cooperation as a characteristic of rural communities is inseparable from the existence of the community as individuals and as social beings. Because humans are in accordance with their qualities able to build themselves, namely humans who know and are aware and have an awareness of their needs. The mutual cooperation that developed in the village community was able to produce community selfreliance and community participation. Community self-reliance can be in the form of the spirit of the villagers to overcome all the problems faced by the village environment. The success of village development so far cannot be separated from the self-reliance of the villagers, due to the limitations of the village development budget. With the existence of self-reliance the villagers are able to produce potential material and / or physical resources in the form of labor to support the implementation of village development. The strong self-reliance of the villagers because it is based on the feeling of brotherhood and the same fate can encourage more villagers to participate in the participatory development process. With the growth and development of social capital can be utilized to support the realization of good governance.

\section{LITERATURE REVIEW}

\section{Social Capital}

Social Capital or Social Capital is the potential that can be invested into social resources, because social capital is the potential to build cooperation in social groups. Social capital comes from individuals in building good cooperation, so that it can strengthen responsibility for achieving group goals. According to Eva Cox (1995) in Martin Baru, et al (2018), social capital is a set of interpersonal relations processes that are supported by networks, social norms and beliefs that enable efficient and effective coordination and cooperation for mutual benefit and virtue. Furthermore Pierre Bourdieu in Sunoto (2014) social capital is a social and cultural aspect that has economic value and can be institutionalized, namely the overall resources both actual and potential related to the ownership of a fixed network of institutional relationships based on mutual recognition and mutual recognition. Furthermore, he said that the amount of social capital owned by a member of a group depends on how far the quantity and quality of the network of relationships that can be created, as well as how much the volume of economic, cultural and social capital is owned by everyone in the relationship network (Rusydi Syahra , 2003). James Coleman (1988), with his research understanding social capital from the aspect of social action, and its relation to social and economic perspectives. From the results of his research, Coleman explained that social capital (social capital) has an important aspect in realizing human capital. There are two elements of the function of social capital, among others: first, social capital covers a number of aspects of social structure, and second, social capital makes it easy for people to do something within the framework of the social structure. He emphasizes two aspects of social structure that are very important in facilitating the creation and development of social capital in various forms. First, the aspect of social structure that creates confinement in a social network that makes each person interconnected in such a way that obligations and sanctions can be imposed on everyone who is a member of that network. Second, the existence of social organizations that can be used to achieve common goals (Rusydi Syahra, 2003). There are three pillars of the potential strength of social capital, firstly the obligations and expectations of individuals in a social group are still well maintained, so as to foster trust in social relations. Second, the potential for social capital can be maintained as long as there is openness among individuals, so as to distance the occurrence of mutual suspicion, mutual distrust which will undermine trust in social relations. Third, social norms and sanctions must be enforced in social relations, so that individuals can always take care of each other and strive to adhere to social norms that have been mutually agreed upon in social groups.

Social capital as well as economic capital has the character to increase productivity too, without the existence of social capital one cannot possibly obtain material and non-material benefits optimally, because social capital 
can encourage and motivate to further enhance cooperation and connectivity in social groups. This is as a result of Robert Putnam's research that: 'features of social organizations, such as networks, norms, and trusts, that facilitate coordination and co-operation for mutual benefits,' characteristics of social organizations, such as networks, norms, and trust that facilitates coordination and cooperation to get mutual benefits. Social capital places more emphasis on the context of horizontal relationships where individuals in social groups are bound to social norms that will produce productivity in the social group. Thus there are two basic assumptions from the concept of social capital from Putnam, namely: the existence of a network of relationships with related norms, and both support each other to achieve success in the economic field for the people included in the network. There are three important reasons for Putnam to say so. First, the existence of social networks allows coordination and communication that can foster mutual trust among fellow community members. Second, trust has positive implications in community life. This is evidenced by the fact that the relationship between people who have mutual trust in a social network strengthens the norms about the need to help each other. The three successes achieved through collaboration at a previous time in this network will encourage the continuation of cooperation at a later time (Rusydi Syahra, 2003). Furthermore, according to Putnam, social capital is a value of mutual trust between members of the community and the community as a whole to its leaders. Social capital is seen as a social institution that involves networks, norms and social trust that encourage a social collaboration (coordination and cooperation) for the common good.

From the point of view above, the social capital can be expanded to benefit in building good social relations between the village government and the villagers. Individuals as citizens of society have the potential for social capital in the form of cooperation that can be used for the benefit of administering village government functions. Cooperation between individual villagers and the village government is a force that can sustain the smooth functioning of government. For this reason, it is an obligation for the village government to build, maintain the potential of social capital within the village community so that they always receive support from the community. One of the main aspects in maintaining the potential of social capital is trust that must be realized by the village government, without the trust/trust of the villagers it is not possible to successfully carry out the tasks of the village government. According to Fukuyama (1995), social capital contains several aspects of values (values), at least there are four values that are very closely related, namely (1) universalism, namely the value of understanding others, appreciation, tolerance and protection of humans and creatures of God, (2) benevolence, namely the value of maintenance and improvement of the welfare of others, (3) tradition, namely the value that contains appreciation, commitment and acceptance of traditional cultural traditions and ideas, and (4) conformity, which is related to self-restraint and action harming others, as well as security values that contain safety, harmony, stability in dealing with others and treating themselves. The potential for social capital develops in individuals, because human beings as creatures of God have mutual respect, respect and tolerance for fellow humans. And those values are always maintained and improved in maintaining the continuity of life and cooperation in community life. The power of social potential is then constructed by individuals or in social groups through social structures in social relations networks. Furthermore Robert Lawang (2005) emphasizes that: social capital refers to all community social forces that are constructed by individuals or groups that refer to social structures which according to their judgment can achieve individual and/or group goals efficiently and effectively with other capital. This definition is explained by Lawang in the sociological perspective as follows; a). Social power refers to all mechanisms that have been and are developed by the community in sustaining their lives. b). Understanding community can refer to micro, mezo and macro communities. Social forces as social capital can be limited to that community which is seen as a bounded social capital or if it has been linked in the form of networks with meso and macro social capital can be referred to as social capital bridging. If the unit of observation and analysis is meso as bounded, the macro is bridging. c). Social capital is basically social construction, meaning, through social interaction individuals build a collective (collective) social power to overcome the social problems faced. d). Social capital in this sense is a means (means) which is constructed by individuals achieving a common goal (end). e). There is a possibility of dominant social capital in overcoming a social problem but it may also not be as important. But the principle of sinerji still applies so that social capital can be used as a social force to achieve common goals (dppka.jogjaprov.go.id/upload/files/good_government.pdf).

Thus, social capital is the social resource of each individual and / or group in the form of social networks, social values, norms, and beliefs. The potential of this social capital can be empowered at any time in supporting village development programs, because village development aims to improve the welfare of the community so that it becomes the glue of cooperation between individuals in people's lives.

\section{Good Governance.}

Good governance has now become a demand for the village community for the implementation of village governance, because the performance of the village administration is still assessed as not in accordance with the expectations of the villagers. Many of the actions and policies produced are less relevant to the needs of the villagers. Therefore, the encouragement of community involvement in the process of village governance became 
increasingly strong when there was a lot of non-departure between the objectives of village development and the needs of the villagers, as well as the occurrence of irregularities in the administration of government functions. Good governance or good governance, according to LAN (2008: 8) contains two meanings. First, values that uphold the wishes or desires of the people, and values that can enhance the ability of the people who achieve the (national) goals of independence for sustainable development and social justice. Second, the functional aspects of government are effective and efficient in carrying out their duties to achieve these objectives. Good governance requires the management of democratic governance, namely providing space and opportunities for the community to be involved in the process of administering the government, with the orientation of management carried out in a transparent, accountable, effective and efficient manner. For this reason, in the development of village governance, a commitment from government administrators is needed to always apply the principles of good governance. According to Mardiasmo (2004: 18), said that: the characteristics of implementing good governance include: a). Participation. Community involvement in making decisions both directly and indirectly through representative institutions that can channel their aspirations. Participation is built on the basis of freedom of association and speech and constructive participation. b). Rule of law. Fair legal framework and carried out indiscriminately. c). Transparency. Transparency is built on the basis of freedom of information. Information relating to public interests can be directly obtained by those who need it. d). Respowiveness. Public institutions must be fast and responsive in serving stakeholders. e). Consensus of orientation. Oriented to the interests of the wider community. f). Equity. Every community has the same opportunity to obtain prosperity and justice. g). Efficiency and effectiveness. Management of public resources is carried out in an efficient (efficient) and effective (effective). h). Accountability. Public accountability for every activity carried out, and i). Strategic vision. Government administrators and the public must have a far-reaching vision.

From the principles of good governance above, there are several important elements in realizing good governance in the implementation of village governance, namely: providing opportunities for villagers to be involved in the formulation of village development policies, the involvement of villagers is intended starting from the identification and development process to implementation and utilization of village development results. According to Lalolo Krina (2007), the principle of participation encourages every citizen to use the right to express opinions in the decision-making process, which concerns the interests of the community, both directly and indirectly. Efforts to encourage community participation can be carried out through village discussion forums, talks, direct consultations with village officials, or it can also be done through participatory planning to prepare the agenda for discussing village development programs and monitoring issues that develop in the community. With the involvement of villagers, it means further strengthening the trust of villagers in their abilities, thus encouraging people to participate in the development process, and at the same time increasing social control in the implementation of village development programs.

Besides that, the implementation of village governance must be managed transparently and accountably, so as to gain the legitimacy and support of the village community for organizing village governance. Accountability in the implementation of village governance is very important, because every activity in carrying out the functions of village government must be accountable to the public. According to Mardiasmo (2003: 26-27), accountability is the ability to account for all actions and policies that have been taken. Every thing carried out by the village government must be known and accountable to the villagers. Whereas transparency must guarantee the existence of information disclosure to the villagers about anything that is carried out by the village government. According to Keban (2000: 51), transparency is the principle that guarantees access or freedom for everyone to obtain information about the administration of government, namely information about policies, the process of making and implementing them, and the results achieved. Information related to the policy-making process, up to the implementation and results of its achievements, the public must know it, so that the government must provide broad access to the public to convey information regarding activities that will, is and has been done. For this reason, transparency requires concrete efforts from the government to open and disseminate relevant information and activities. With the principle of transparency, it will create mutual trust between the government and the community through the provision of information and ensure convenience in obtaining accurate and adequate information. According to Meutia Gani and Rochman (2000: 7), transparency is the existence of an open policy for supervision and what is meant by information is information about every aspect of government policy that can be reached by the public. Information disclosure is expected to result in healthy, tolerant political competition, and policies made based on public preferences. This principle has two aspects, namely (1) the dissemination of information about public finance by the government, (2) the availability of community rights to access information, (3) the existence of a forum to accommodate the interests of the public to convey information about public finance (4) accommodation of community interests in public budgeting. These things require the government to improve its performance, as a good starting point for implementing transparency. Furthermore, in its explanation, transparency is a principle that guarantees access or freedom for everyone to obtain information about governance, namely information about policies, the process of making and implementing them, and the results achieved. Transparency is the existence of an open policy for supervision. While what is meant by information is information 
about every aspect of government policy that can be reached by the public. Information disclosure is expected to result in healthy, tolerant political competition and policies made based on public preferences (Meuthia GR, 2000). This principle has two aspects, namely public communication by the government, and people's rights to access information. Both will be very difficult to do if the government does not handle its performance well.

Dari pokok pikiran kedua variabel diatas, menunjukkan bahwa potensi modal sosial sebagai potensi sumber daya sosial yang sangat penting untuk mendukung terwujudnya tata kelola pemerintahan desa yang baik (good governance). Untuk itu, dapat dijelaskan melalui pengembangan hipotesis berikut dikontruksikan hubungannya antar variabel yaitu:

$H 0=$ There is no influence between the Potential of Social Capital towards rural good governance,

$H a=$ There is an influence between the potential of social capital towards rural good governance.

Picture. 1

Research Structure of the Potential of Social Capital and Rural Good Governance

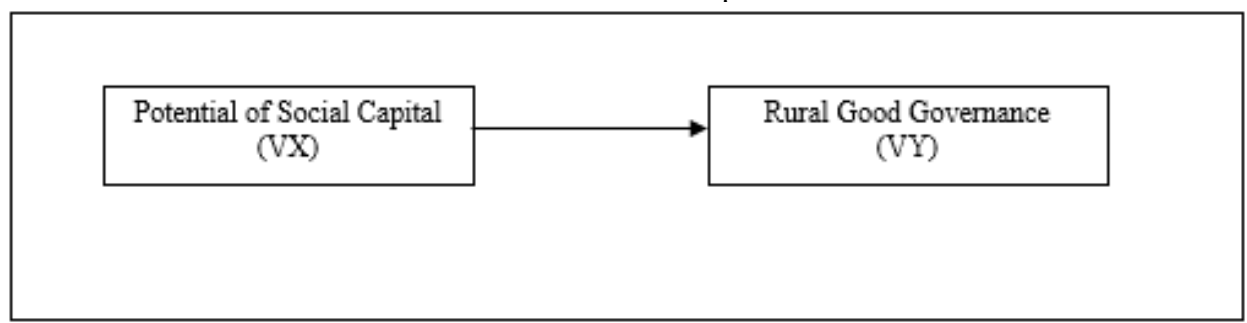

\section{RESEARCH METHODS}

This study uses a quantitative approach to determine respondents' assessment of the potential of social capital, and good governance. Data was collected through distributing questionnaires to 120 respondents who were randomly selected in 6 villages in Madiun Regency. Each village was assigned 20 respondents by stratified random sampling, which consisted of: village heads and village officials, BPD, LKMD, community leaders, PKK, and the community. Respondents' assessment was measured using a Likert scale with gradations from very positive to very negative, in the form of words such as: a) Strongly agree with a score of 5, b) agree with a score of 4 , c) Hesitate with a score of 3, d) No agree with the score 2, and e) Strongly disagree with the score 1 . While the method of data analysis uses a regression analysis model with processing through SPSS.

\section{RESULTS AND DISCUSSION}

\section{Test Correlation.}

For the hypothesis test, a correlation test between the Potential Social Capital (VX) variable as an independent variable on rural good governance (VY) as the dependent variable is conducted. The correlation test results are as follows:

Table. 1

Correlation Test Result between the Potential Social Capital variable and rural good governance

Correlations

\begin{tabular}{|ll|r|r|}
\hline & & $\begin{array}{c}\text { Potential Social } \\
\text { Capital }\end{array}$ & \multicolumn{1}{|c|}{$\begin{array}{c}\text { Rural good } \\
\text { governance }\end{array}$} \\
\hline $\begin{array}{llr}\text { Potential Social } \\
\text { Capital }\end{array}$ & Pearson Correlation & 1 & $.667^{* *}$ \\
& Sig. (2-tailed) & 150 & .000 \\
& $\mathrm{~N}$ & $.667^{* *}$ & 150 \\
\hline Rural good & Pearson Correlation & .000 & 1 \\
governance & Sig. (2-tailed) & 150 & 150 \\
& $\mathrm{~N}$ &
\end{tabular}

From the table above, the correlation value between the variables of potential social capital and the village governance variable is 0.667 with a value of $p$ value $=0,000$. When compared with the value of $\alpha=0.05$, it is known that $\mathrm{p}$ value $=(0,000)<\alpha(0.05)$. Thus, the Ha hypothesis is accepted, namely there is a correlation between the potential of social capital and village governance. 


\section{Regression Test}

The results of the regression calculation between the potential variables of social capital for village governance are:

Table. 2

Regression Test Result between the Potential Social Capital variable and rural good governance

Coefficients $^{\mathbf{a}}$

\begin{tabular}{|c|c|c|c|c|c|}
\hline \multirow[b]{2}{*}{ Model } & \multicolumn{2}{|c|}{ Unstandardized Coefficients } & $\begin{array}{l}\text { Standardized } \\
\text { Coefficients }\end{array}$ & \multirow[b]{2}{*}{$\mathrm{T}$} & \multirow[b]{2}{*}{ Sig. } \\
\hline & $\mathrm{B}$ & Std. Error & Beta & & \\
\hline $1 \quad$ (Constant) & 7.922 & 4.654 & & 1.702 & .091 \\
\hline $\begin{array}{l}\text { Potential Social } \\
\text { Capital }\end{array}$ & .859 & .079 & .667 & 10.884 & .000 \\
\hline
\end{tabular}

a. Dependent Variable: rural good governance

From the regression equation $(\mathrm{Y}=\mathrm{a}+\mathrm{bX}$ ), it can be identified: (1) Constant value 7.922; indicates that village governance will be constant if the potential variable of social capital is zero (none), assuming other factors remain or do not change in value. (2) Variable potential for social capital worth 0.859 (positive) indicates the influence of potential social capital on village governance. If the potential for social capital increases by 1 unit, village governance also increases by 0.859 . Thus the potential for social capital has a positive influence on village governance.

Determination Test.

The coefficient of determination (R2) is used to measure how far the model's ability to explain variations in the dependent variable (Ghozali, 2006). The test results of the coefficient of determination are:

Table. 3

Determination Test Results between the variables of Potential Social Capital and rural good governance

Model Summary ${ }^{b}$

\begin{tabular}{|l|r|r|r|r|}
\hline Model & $\mathrm{R}$ & R Square & \multicolumn{1}{|c|}{$\begin{array}{c}\text { Adjusted R } \\
\text { Square }\end{array}$} & \multicolumn{2}{|c|}{$\begin{array}{c}\text { Std. Error of the } \\
\text { Estimate }\end{array}$} \\
\hline 1 & $.667^{\mathrm{a}}$ & .445 & .441 & 7.112 \\
\hline
\end{tabular}

a. Predictors: (Constant), Potential Social Capital

b. Dependent Variable: rural good governance

The amount of Multiple Coefficient of Determination ( $\mathrm{R}$ Square) is 0.445 or $44.5 \%$, which means that the potential of social capital can be explained by variables of village governance, while the remaining $55.5 \%$ is explained by other variables not explained in this study. Social capital can be a potential force if the trust of the villagers towards village government organizers, the growth of trust can encourage cooperation with the synergy between villagers and village government officials. Therefore, to realize good governance, trust is needed that can be generated through various village government policies and the behavior of village officials who are able to provide good public services.

\section{CONCLUSION.}

Social capital as a potential can be utilized to support the administration of government functions, if there are village villagers' trust in the village government. Trusts can be generated if the village government work program produced is truly oriented to the interests of the villagers, as well as the behavior orientation of village officials who are able to provide good service to the village community. The trust will generate synergy between the potential of social capital and the potential of village officials, so that it can be a force that can be utilized to realize good governance.

\section{CONFLICT OF INTEREST}

There is no conflict of interest.

\section{ACKNOWLEDGMENTS}

This article is sponsored by the Kemenristik-Dikti Indonesian Research Grants Program. 


\section{REFERENCES}

Fukuyama, Francis.1995. Trust: Kebajikan Sosial dan Penciptaan Kemakmuran. Terjemahan, Yogyakarta: Penerbit Qalam.

Ganie-Rochman, Meuthia dalam artikel berjudul "Good governance : Prinsip, Komponen dan Penerapannya", dalam buku HAM : Penyelenggaraan Negara Yang Baik \& Masyarakat Warga. Komnas HAM, Jakarta. 2000

Ghozali, Imam, 2006, Aplikasi Analisis Multivariate Dengan Program SPSS, Semarang, Badan Penerbit Universitas Diponegoro.

Keban, Yeremeas, T, 2000, Enam Dimensi Strategis Administrasi Publik: Konsep, Teori dan Issue, Yogyakarta: Pustaka Gava Media.

Kusnaedi. 2006. Mengolah Air Gambut dan Air Kotor untuk Air Minum. Cetakan ke-15. Jakarta: Penebar Swadaya. Lembaga Administrasi Negara-Republik Indonesia, 2008, Operasional Pelayanan Prima, Modul Pendidikan dan Pelatihan Kepemimpinan Tingkat IV.

Lalolo Krina, 2007, Indikator Dan Tolok Ukur Akuntabilitas, Transparansi dan Partisipasi. Sekretariat Pengembangan Kebijakan Nasional Tata Kepemrintahan yang Baik, BAPPENAS

Lawang, Robert M.Z, 2004, Kapital Sosial dalam Perspektif Sosiologik, FISIP UI Press : Depok

Mardiasmo, 2004, Otonomi \& Manajemen Keuangan Daerah, Yogyakarta: Penerbit ANDI.

Bambang Martin Baru, dkk, 2017, Pendayagunaan Modal Sosial (Social Capital) dalam Penguatan Lembaga Pemerintah Desa, Bagi terwujudnya Pemerintahan yang baik (Good Governance), dikti, Jakarta.

................, 2018, Pendayagunaan Modal Sosial (Social Capital) dalam Penguatan Lembaga Pemerintah Desa, Bagi terwujudnya Pemerintahan yang baik (Good Governance), dikti, Jakarta.

................., 2017, Utilization of Social Capital in Strengthening Village Government Institutions, Journal of Research on Humanities and Social Sciences, Vol. 7, No 16,

https://www.iiste.org/Journals/index.php/RHSS/article/view/38489

.................., 2018, Development of Village Based Potentials of Social Capital in Madiun District, East Java, Indonesia, Jurnal Research on Humanities and Social Sciences, Vol 8, No 14 (2018) - Iiste.org, https://www.iiste.org/Journals/index.php/RHSS/issue/view/3606

Rusydi Syahra, Modal Sosial: Konsep dan Aplikasi, Jurnal Masyarakat dan Budaya, Volume 5 No. 1 Tahun 2003 Widjaja, AW, 2004, Otonomi Desa: Merupakan Otonomi yang Asli, Bulat dan Utuh, Jakarta: Penerbit Rajawali Pers

dppka.jogjaprov.go.id/upload/files/good_government.pdf, diakses tanggal. 4 Mei 2019. 